\title{
Sr ISOTOPIC COMPOSITION OF FINNISH RAPAKIVI GRANITES: THE SUOMENNIEMI BATHOLITH
}

\author{
TAPANI RÄMÖ
}

\begin{abstract}
RÄMÖ, TAPANI 1999. Sr isotopic composition of Finnish rapakivi granites: the Suomenniemi batholith. Bulletin of the Geological Society of Finland 71, Part 2, 339-345.

Key words: granites, rapakivi, batholiths, geochemistry, isotopes, $\mathrm{Rb} / \mathrm{Sr}$, Proterozoic, Suomenniemi, Finland

Tapani Rämö: Department of Geology, P.O. Box 11, FIN-00014 University of Helsinki, Finland.

E-mail: tapani.ramo@helsinki.fi
\end{abstract}

\section{INTRODUCTION}

The Proterozoic rapakivi granites and related rocks have recently been the subject of active research that has employed petrological, mineralogical, geochemical, and geophysical methods (see Rämö \& Haapala 1995 and Haapala \& Rämö 1999 and references in these articles). Isotope geochemical studies, in particular, have turned out to be powerful in assessing the origin and protolith history of the rapakivi granites and the mafic rocks associated with them (e.g., Rämö 1991, Haapala \& Rämö 1992, Fröjdö et al. 1996, Rämö et al. 1996, Andersson 1997). The classic rapakivi granites of southeastern Fennoscandia are believed to have crystallized from anatectic melts derived from deep, yet crustal, sources (e.g., Haapala \& Rämö 1992). The contemporaneous mafic rocks (gabbroids, anorthosites, diabase dikes) presumably represent derivatives of the mantle-originated thermal perturbations that caused anatexis of deep parts of the crust and subsequent emplacement of rapakivi granite batholiths in an extensional tectonic setting.

Differences in the initial $\mathrm{Nd}$ and $\mathrm{Pb}$ isotopic composition between the silicic and mafic rocks of the rapakivi occurrences of the Fennoscandian Shield have been found to be quite small, regardless of whether they are associated with Paleoproterozoic (Rämö 1991, Fröjdö et al. 1996, Lindh \& Johansson 1996) or Archean (Neymark et al. 1994, Andersson 1997, Persson 1997) lithosphere. A comagmatic relationship for the contrasting rock types has, however, been considered unlikely on combined isotopic-petrological reasoning (e.g., Rämö 1991, Salonsaari 1995, Andersson 1997). The purpose of this communication is to present $\mathrm{Sr}$ isotopic data on one of the southeastern Finnish rapakivi granite plutons and to make a note on the petrogenetic relationship of the silicic and mafic rocks of the classic rapakivi association of Finland from that perspective. 


\section{GEOLOGICAL SETTING AND SAMPLES}

The $\mathrm{Sr}$ isotopic data presented here come from the Suomenniemi rapakivi batholith situated on the northern flank of the Wiborg batholith in southeastern Finland (Fig. 1). The lithology, geochemistry (including $\mathrm{Nd}$ and $\mathrm{Pb}$ isotopes), and geochronology of the Suomenniemi batholith have been studied in considerable detail (Rämö 1991, Vaasjoki et al. 1991). The batholith includes four main granite rock types (Fig. 1): hornblende granite, biotite-hornblende granite, biotite granite, and topaz-bearing alkali-feldspar granite. One sample of hornblende granite and two biotite granites have yielded $\mathrm{U}-\mathrm{Pb}$ zircon ages that cluster tightly at $1640 \mathrm{Ma}(1641 \pm 2,1641 \pm 1$, and $1639 \pm 6$ Ma; Vaasjoki et al. 1991). Rämö (1991) concluded that the four main granite types of the batholith probably form a fractionation series that can be related to a common, relatively silicic parental magma; the latter was presumably generated by partial melting of an intermediate to silicic deep crustal source. The most highly fractionated topazbearing alkali-feldspar granites in the nothern parts

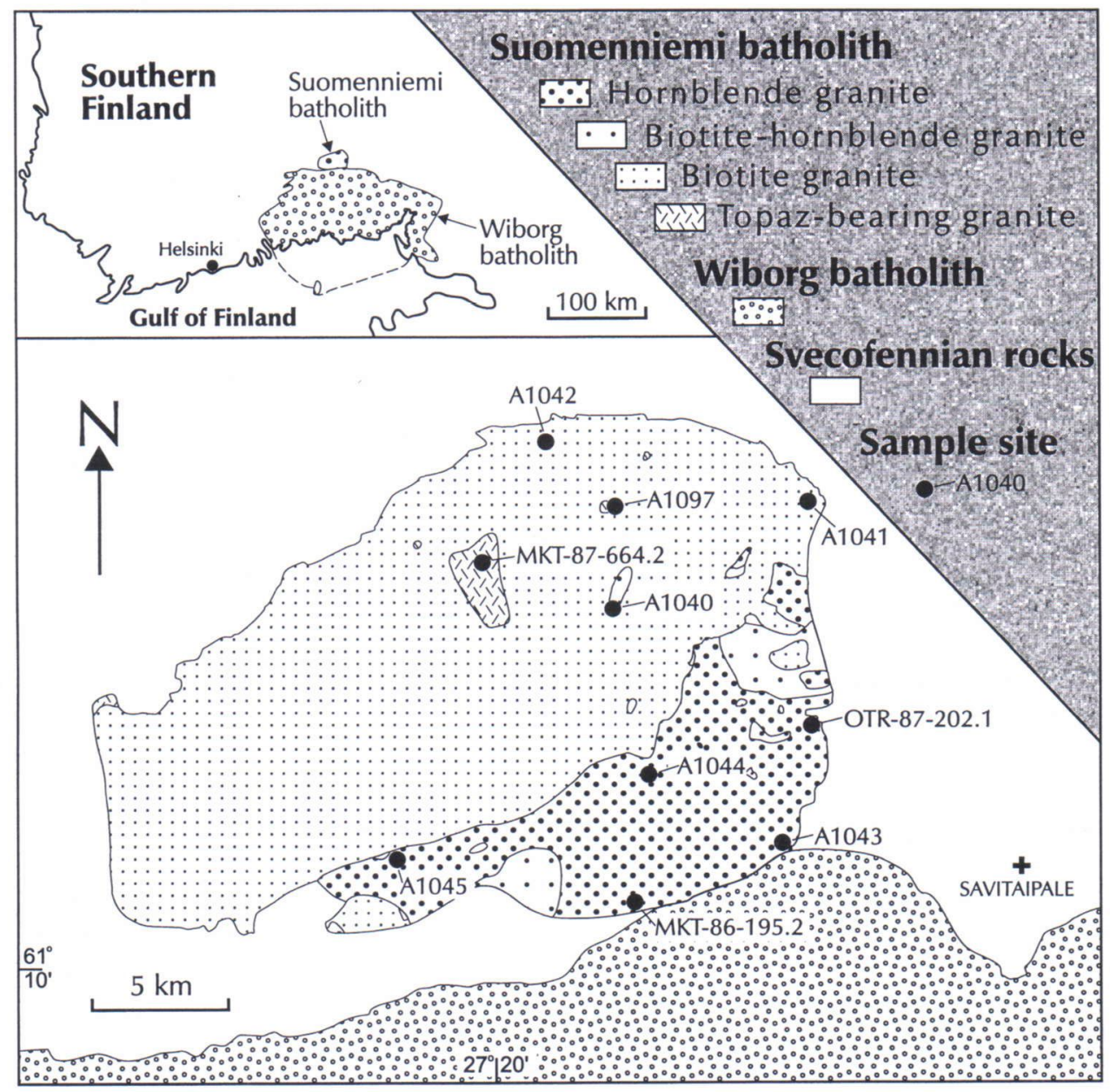

Fig. 1. Geologic sketch map showing the location of the Wiborg and Suomenniemi rapakivi granite batholiths, distribution of the main granite types in the latter, and sample sites for Rb-Sr isotope analysis. Simplified from Appendix 4 in Rämö (1991). 
of the batholith also show evidence for subsolidus compositional changes, e.g., anomalously high $\mathrm{Rb}$ and low Sr concentrations (Rämö 1991).

In total ten samples were chosen for $\mathrm{Rb}-\mathrm{Sr}$ isotope analysis from the main granite types of the Suomenniemi batholith (Fig. 1, Table 1). Five of them (OTR-87-202.1, MKT-86-195.2, A1043, A1044, A1045) are from the hornblende granite in the southern and southeastern part of the batholith, and five (A1040, A1041, A1042, MKT-87664.2, A1097) are from the biotite-hornblende, biotite, and topaz-bearing granites in the central and northern parts of the batholith. Sampling was focused on the hornblende granites as they were known to have much lower $\mathrm{Rb}-\mathrm{Sr}$ ratios than the other, more evolved, granite types and thus were likely to have experienced less dramatic subsolidus changes that might have affected the $\mathrm{Rb}-\mathrm{Sr}$ isotopic system.

\section{RESULTS}

The $\mathrm{Sr}$ isotopic data for the ten samples are listed in Table 1 and shown in a Rb-Sr isochron diagram in Fig. 2. The samples show an overall increase in the $\mathrm{Rb}-\mathrm{Sr}$ ratio from the hornblende granites $(\mathrm{Rb} / \mathrm{Sr} \sim 1)$ to the topaz-bearing granites ( $\mathrm{Rb} / \mathrm{Sr} \sim 77$ in sample A1097). Likewise, the measured ${ }^{87} \mathrm{Sr}-{ }^{86} \mathrm{Sr}$ ratios range from relatively low ( 0.76 in hornblende granite sample OTR-87202.1) to extremely high ( 10.8 in topaz-bearing granite A1097). The $\mathrm{Rb}-\mathrm{Sr}$ and ${ }^{87} \mathrm{Sr}-{ }^{86} \mathrm{Sr}$ ratios in the Proterozoic rapakivi granites are higher than in granitic rocks in general and reflect their low overall Sr content (cf. Rämö \& Haapala 1995, Rämö et al. 1996). Calculated back to the U-Pb (presumable crystallization) age of the batholith, the ${ }^{87} \mathrm{Sr}-{ }^{86} \mathrm{Sr}$ ratios of the individual granite samples vary widely (from 0.4316 to 0.7082 ; Table 1) and fail to register an initial $\mathrm{Sr}$ isotopic composition for the batholith. In the $\mathrm{Rb}-\mathrm{Sr}$ isochron diagram (Fig. 2), the samples fall on a trend with a slope corresponding to an age of $1600 \pm 7 \mathrm{Ma}$, initial ${ }^{87} \mathrm{Sr}-{ }^{86} \mathrm{Sr}$ ratio of $0.7066 \pm 0.0023$, and M.S.W.D. (Mean Square of Weighted Deviates) of 28.9. Using this age, the time-corrected ${ }^{87} \mathrm{Sr}-$
${ }^{86} \mathrm{Sr}$ ratios (Table 1) correspond rather well to the initial ratio of the $\mathrm{Rb}$-Sr errorchron (Fig. 2), save for the four samples with the highest $\mathrm{Rb}-\mathrm{Sr}$ ratios (biotite granites and topaz-bearing granites).

\section{DISCUSSION AND CONCLUSIONS}

The age registered by the $\mathrm{Rb}-\mathrm{Sr}$ system of the granites of the Suomenniemi batholith, $1600 \pm$ $7 \mathrm{Ma}$, is measurably lower than the $1640 \mathrm{Ma} \mathrm{U}-\mathrm{Pb}$ age (Vaasjoki et al. 1991) and probably represents a cooling age by which subsolidus migration of $\mathrm{Rb}$ and $\mathrm{Sr}$ between mineral grains had ceased in the batholith. Rb-Sr whole rock ages have often been reported to be substantially younger than $\mathrm{U}-\mathrm{Pb}$ ages in granitic plutons, and have been ascribed to slow cooling of the plutons and/or subsequent thermal events (see Welin et al. 1983, Kähkönen et al. 1989, Haudenschild 1995 and references in these articles) or to heterogeneous initial Sr isotopic composition (Romer 1994). The age difference in the Suomeniemi batholith - at minimum, $\sim 30 \mathrm{Ma}$ - is small and may reflect the relatively small size of the intrusion, the overall $\mathrm{H}_{2} \mathrm{O}$-poor nature of the rapakivi granite magma, and the fact that the batholith presumably crystallized from a single batch of granite magma that probably was relatively homogeneous in terms of its initial ${ }^{87} \mathrm{Sr}-{ }^{86} \mathrm{Sr}$ ratio.

The four samples with the highest $\mathrm{Rb}-\mathrm{Sr}$ ratios show the largest deviations from the calculated errorchron (i.e., their initial ratios at $1600 \mathrm{Ma}$ are clearly different from that of the errorchron) which suggests that their igneous $\mathrm{Rb}-\mathrm{Sr}$ ratios were substantially changed at the subsolidus stage. This could have happened by way of exhange reactions between the granites and autometasomatic fluids that leached $\mathrm{Sr}$ out of the granites (e.g., deanorthization of plagioclase) and added $\mathrm{Rb}$ to altered feldspars and micas (see Haapala 1997).

As a result of the apparent low $\mathrm{Rb}-\mathrm{Sr}$ age of the batholith, the calculated initial ${ }^{87} \mathrm{Sr}-{ }^{86} \mathrm{Sr}$ ratio, $0.7066 \pm 0.0023$, is somewhat higher than the ${ }^{87} \mathrm{Sr}-$ ${ }^{86} \mathrm{Sr}$ ratio of the magma from which the granites of the batholith probably crystallized $1640 \mathrm{Ma}$ ago. A rough estimate of this difference can be 
Table 1. Whole-rock Rb-Sr isotopic data for the Suomenniemi rapakivi granite batholith, southeastern Finland

\begin{tabular}{|c|c|c|c|c|c|c|c|c|}
\hline Sample & $\begin{array}{l}\text { Location } \\
\text { (Map; Northing; Easting) }\end{array}$ & $\begin{array}{c}\mathrm{Rb} \\
\text { (p.p.m.) }\end{array}$ & $\begin{array}{c}\mathrm{Sr} \\
\text { (p.p.m.) }\end{array}$ & $\mathrm{Rb} / \mathrm{Sr} *$ & ${ }^{87} \mathrm{Rb}^{86} \mathrm{Sr}^{\dagger}$ & $\begin{array}{l}{ }^{87} \mathrm{Sr} /{ }^{86} \mathrm{Sr} \\
\text { (at present) }\end{array}$ & $\begin{array}{c}{ }^{87} \mathrm{Sr} /{ }^{86} \mathrm{Sr} \\
(1640 \mathrm{Ma} \text { ago }) \\
\end{array}$ & $\begin{array}{c}{ }^{87} \mathrm{Sr} /{ }^{86} \mathrm{Sr} \\
(1600 \mathrm{Ma} \text { ago })\end{array}$ \\
\hline \multicolumn{9}{|c|}{ Hornblende granite } \\
\hline OTR-87-202.1 & 313209C; 6793.32; 3529.85 & 144.9 & 190.1 & 0.762 & 2.217 & $0.760419 \pm 27$ & 0.70819 & 0.70948 \\
\hline MKT-86-195.2 & $313208 \mathrm{~B} ; 6786.85 ; 3523.68$ & 182.0 & 156.2 & 1.17 & 3.398 & $0.786347 \pm 24$ & 0.70628 & 0.70826 \\
\hline A1043 & $313208 \mathrm{D} ; 6788.76 ; 3528.02$ & 177.2 & 169.1 & 1.05 & 3.052 & $0.777363 \pm 16$ & 0.70546 & 0.70723 \\
\hline A1044 & 313209A; 6791.44; 3523.57 & 238.6 & 78.75 & 3.03 & 8.942 & $0.913227 \pm 15$ & 0.70256 & 0.70776 \\
\hline A1045 & $313205 \mathrm{~B} ; 6788.64 ; 3513.94$ & 255.1 & 151.1 & 1.69 & 4.935 & $0.818894 \pm 15$ & 0.70261 & 0.70548 \\
\hline \multicolumn{6}{|c|}{ Biotite-hornblende granite } & $0.862640 \pm 10$ & 0.70155 & 0.70552 \\
\hline \multicolumn{9}{|l|}{ Biotite granite } \\
\hline A1041 & 314107C; 6801.70; 3529.38 & 351.0 & 58.35 & 6.02 & 18.10 & $1.119189 \pm 18$ & 0.69276 & 0.70328 \\
\hline A1042 & $314104 \mathrm{C} ; 6803.94 ; 3519.30$ & 321.6 & 65.93 & 4.88 & 14.57 & $1.039237 \pm 15$ & 0.69595 & 0.70442 \\
\hline \multicolumn{9}{|c|}{ Topaz-bearing granite } \\
\hline MKT-87-664.2 & 313206D; 6799.43; 3517.25 & 683.0 & 19.10 & 35.8 & 134.9 & $3.82024 \pm 6$ & 0.64166 & 0.72010 \\
\hline A1097 & $314107 \mathrm{~A} ; 6801.54 ; 3521.84$ & 695.9 & 9.064 & 76.8 & 442.4 & $10.84869 \pm 24$ & 0.43157 & 0.68873 \\
\hline
\end{tabular}

Note: The isotopic analyses were carried out at the Unit for Isotope Geology, Geological Survey of Finland. For details of the analytical procedure, see Rämö et al. (1996).

* Weight ratio.

$\dagger$ Atomic ratio; estimated error is better than $0.5 \%$.

$\ddagger$ Normalized to ${ }^{86} \mathrm{Sr} /{ }^{88} \mathrm{Sr}=0.1194$. Within-run precision expressed as $2 \sigma_{\mathrm{m}}$ in the last significant digits; external error is $0.009 \%$ ( $2 \sigma$ ). 


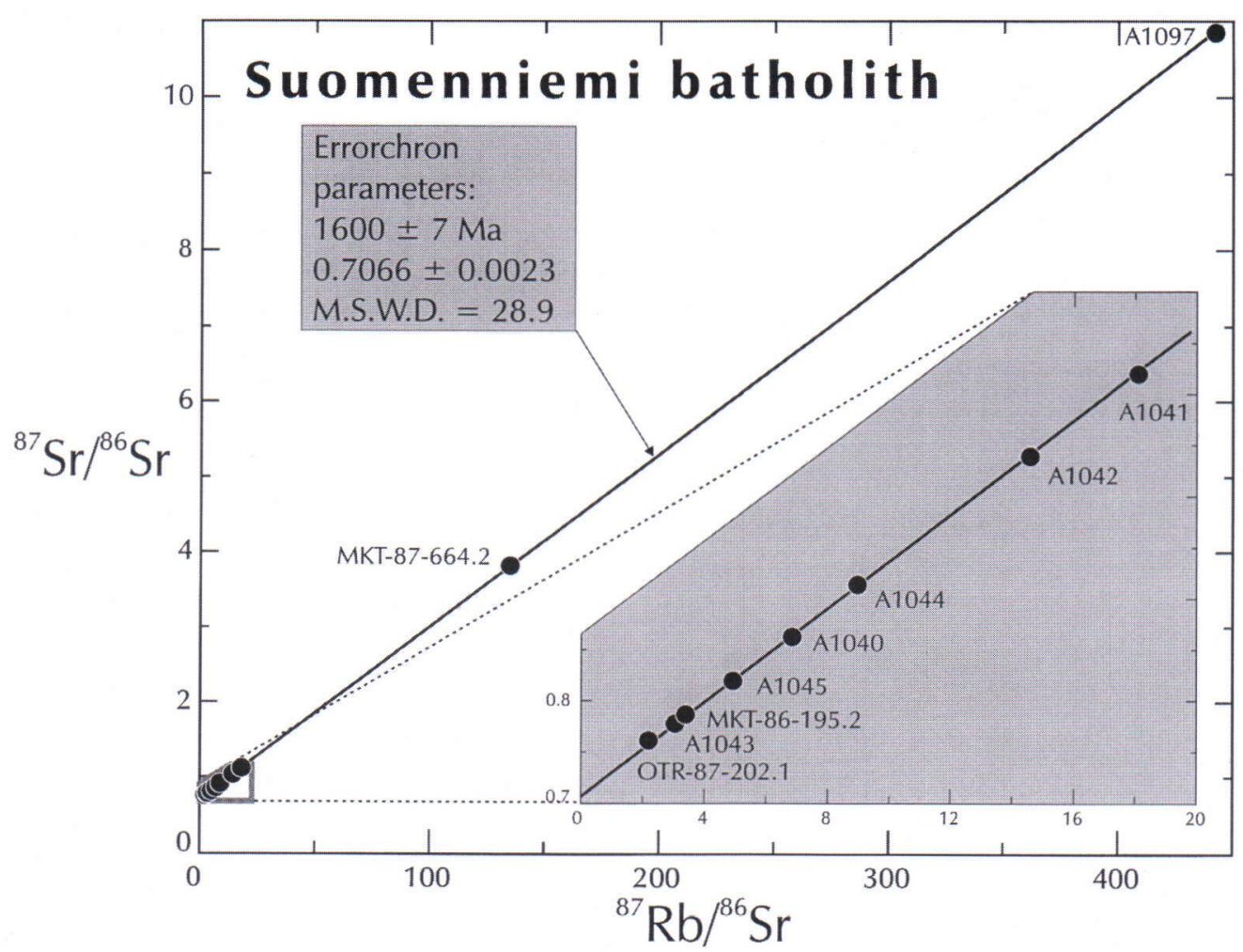

Fig. $2 .{ }^{87} \mathrm{Rb}{ }^{86} \mathrm{Sr}$ vs. ${ }^{87} \mathrm{Sr}{ }^{86} \mathrm{Sr}$ diagram for the main granite types of the Suomenniemi rapakivi granite batholith of southeastern Finland.

obtained by choosing a lower $\mathrm{Rb}-\mathrm{Sr}$ ratio for the highest- $\mathrm{Rb} / \mathrm{Sr}$ topaz-bearing granite sample so that a fictious $1640 \mathrm{Ma} \mathrm{Rb}-\mathrm{Sr}$ isochron is obtained. To do this, I used the lowest- $\mathrm{Rb} / \mathrm{Sr}$ hornblende granite sample OTR-87-202.1 and the highest- $\mathrm{Rb} / \mathrm{Sr}$ topaz-bearing granite sample A1097 and lowered the $\mathrm{Rb}-\mathrm{Sr}$ ratio of the latter to get a $1640 \mathrm{Ma}$ slope for the line through the two points; for this, a 2.7 $\%$ decrease in the ${ }^{87} \mathrm{Rb}-{ }^{86} \mathrm{Sr}$ ratio (from 442.4 to 430.5) was required. The corresponding decrease in the initial ${ }^{87} \mathrm{Sr}-{ }^{86} \mathrm{Sr}$ ratio was $0.2 \%$, that is from 0.7066 to 0.7052 , which is well within the $2 \sigma$ error of $\pm 0.33 \%( \pm 0.0023)$ calculated from the actual data. Thus the initial ratio of $0.7066 \pm 0.0023$ can be considered a fair estimate of the initial ratio of the Suomenniemi batholith.

The initial ratio of $0.7066 \pm 0.0023$ is comparable to the initial ratio presented for five whole rocks from the southwest Finnish Alland rapakivi granite batholith by Suominen (1991). The Åland samples fall on a trend with an age of approximately $1520 \mathrm{Ma}$ and initial ratio of $0.706 \pm 0.003$ (see Table 16 in Suominen 1991). As the difference between the $\mathrm{U}-\mathrm{Pb}$ age $(\sim 1575 \mathrm{Ma})$ and the $\mathrm{Rb}-\mathrm{Sr}$ age of the Aland batholith is somewhat greater than that of the Suomenniemi batholith, the initial ratio for Åland is less well-defined, yet of the same order.

Initial $\mathrm{Sr}$ isotopic compositions for three Subjotnian diabase dikes associated with the Finnish rapakivi granites have been published by Suominen (1991). Two dikes (Föglö, Kumlinge) from the Aland area and one dike (Ansio) from the Häme dike swarm west-northwest of the Wiborg batholith (Laitakari 1987) all have initial ratios on the order of $0.7035-0.7036$ and thus plot on the evolution curve of average subcontinental mantle (see Fig. 8 in Rämö et al. 1996). Similar initial ratios have recently also been measured for the gabbroic and anorthositic rocks of the $1640 \mathrm{Ma}$ 
Ahvenisto rapakivi granite - massif-type anorthosite complex just west of the Suomenniemi batholith (Rämö et al. 1999; see also Alviola et al. 1999). These figures are, at face value and presumably also if the experimental errors are considered, distinctly lower than the initial ratio of the Suomenniemi batholith and suggest that the mafic and silicic rocks were derived from different protoliths, the former from a mantle source and the latter probably from a relatively $\mathrm{Rb}$-poor lower crustal domain.

ACKNOWLEDGMENTS. I gladly acknowledge the help from the staff of the Unit for Isotope Geology, Geological Survey of Finland, especially Hannu Huhma, Matti Vaasjoki, Irmeli Mänttäri, Tuula Hokkanen, Marita Niemelä, Arto Pulkkinen, Lasse Heikkinen, and Matti Karhunen, while making the isotope analyses. I am grateful to Ulf B. Andersson (Uppsala) and Hugh E. $O$ 'Brien (Espoo) for constructive comments on the manuscript. Financial support from the Academy of Finland is also acknowledged. This is a contribution to IGCP Project 426 "Granite Systems and Proterozoic Lithospheric Processes”.

\section{REFERENCES}

Alviola, R., Johanson, B.S., Rämö, O.T. \& Vaasjoki, M. 1999. The Proterozoic Ahvenisto rapakivi granite - massif-type anorthosite complex, southeastern Finland; Petrography and U-Pb chronology. In: Haapala, I. \& Rämö, O.T. (eds.) Rapakivi granites and related rocks. Precambrian Research 95, 89-107.

Andersson, U.B. 1997. Petrogenesis of some Proterozoic granitoid suites and associated basic rocks in Sweden (geochemistry and isotope geology). Sveriges Geologiska Undersökning, Rapporter och meddelanden nr 9. $216 \mathrm{p}$.

Fröjdö, S., Andersson, U.B. \& Claesson, S. 1996. Nd isotope geochemistry of some mafic rocks and minerals associated with the Mesoproterozoic Åland and Nordingrå rapakivi batholiths, Fennoscandian Shield. In: Proterozoic evolution in the North Atlantic realm, Program and Abstracts, 29 July - 2 August, 1996, Goose Bay, Labrador, 62-63.

Haapala, I. 1997. Magmatic and postmagmatic processes in tin-mineralized granites: topaz-bearing leucogranite in the Eurajoki rapakivi granite stock, Finland. Journal of Petrology 38, 1645-1659.

Haapala, I. \& Rämö, O.T. 1992. Tectonic setting and ori- gin of the Proterozoic rapakivi granites of southeastern Fennoscandia. Transactions of the Royal Society of Edinburgh: Earth Sciences 83, 165-171.

Haapala, I. \& Rämö, O.T. 1999. Rapakivi granites and related rocks: an introduction. Precambrian Research 95, $1-7$.

Haudenschild, U. 1995. The Vaaraslahti pyroxene granitoid intrusion and its contact aureole: isotope geology. In: Hölttä, P. (ed.) Relationship of granitoids, structures and metamorphism of the eastern margin of the Central Finland Granitoid Complex. Geological Survey of Finland, Bulletin 382, 81-89.

Kähkönen, Y., Huhma, H. \& Aro, K. 1989. U-Pb zircon ages and $\mathrm{Rb}-\mathrm{Sr}$ whole rock isotope studies of early Proterozoic volcanic and plutonic rocks near Tampere, southern Finland. Precambrian Research 45, 27-43.

Laitakari, I. 1987. Hämeen subjotuninen diabaasijuoniparvi. English abstract: The Subjotnian diabase dyke swarm of Häme. In: Aro, K. \& Laitakari, I. (eds.) Suomen diabaasit ja muut mafiset juonikivilajit (Diabases and other mafic dyke rocks in Finland). Geological Survey of Finland, Report of Investigation 76, 99-116.

Lindh, A. \& Johansson, I. 1996. Rapakivi granites of the Baltic Shield: the Nordingrå granite, its chemical variation and Sm-Nd isotope composition. Neues Jahrbuch für Mineralogie, Abhandlungen 170, 291-312.

Neymark, L.A., Amelin, Yu.V. \& Larin, A.M. 1994. Pb$\mathrm{Nd}-\mathrm{Sr}$ isotopic constraints on the origin on the 1.54-1.56 Ga Salmi rapakivi granite-anorthosite batholith (Karelia, Russia). Mineralogy and Petrology 50, 173-194.

Persson, A.I. 1997. The Ragunda rapakivi granite complex. In: Ahl, M., Andersson, U.B., Lundqvist, T. \& Sundblad, K. (eds.) Rapakivi granites and related rocks in central Sweden. Sveriges Geologiska Undersökning $\mathrm{Ca}$ 87, 49-58.

Rämö, O.T. 1991. Petrogenesis of the Proterozoic rapakivi granites and related basic rocks of southeastern Fennoscandia: $\mathrm{Nd}$ and $\mathrm{Pb}$ isotopic and general geochemical constraints. Geological Survey of Finland, Bulletin 355. $161 \mathrm{p}$.

Rämö, O.T. \& Haapala, I. 1995. One hundred years of Rapakivi Granite. Mineralogy and Petrology 52, 129-185.

Rämö, O.T., Huhma, H. \& Kirs, J. 1996. Radiogenic isotopes of the Estonian and Latvian rapakivi granite suites: new data from the concealed Precambrian of the East European Craton. Precambrian Research 79, 209-226.

Rämö, O.T., Nironen, M., Kosunen, P. \& Elliott, B.A. 1999. Proterozoic Granites of South-Central Finland Traverse Across a Paleoproterozoic Terrane Boundary. IGCP Project 426 Field Trip to Southern and Central Finland, September 13-18, 1999, Field Trip Guide. Helsinki University Press. 106 p.

Romer, R.L. 1994. Rb-Sr data structure - a possible cause for differences in $\mathrm{Rb}-\mathrm{Sr}$ whole-rock and $\mathrm{U}-\mathrm{Pb}$ zircon ages. GFF (formerly Geologiska Föreningens i Stockholm Förhandlingar) 116, 93-103.

Salonsaari, P.T. 1995. Hybridization in the bimodal Jaala-Iitti complex and its petrogenetic relationship to rapakivi granites and associated mafic rocks of southeast- 
ern Finland. Bulletin of the Geological Society of Finland 67, Part 1b. 104 p.

Suominen, V. 1991. The chronostratigraphy of SW Finland with special reference to the Postjotnian and Subjotnian diabases. Geological Survey of Finland, Bulletin 356. $100 \mathrm{p}$.

Vaasjoki, M., Rämö, O.T. \& Sakko, M. 1991. New U-Pb ages from the Wiborg rapakivi area: constraints on the temporal evolution of the rapakivi granite - anorthosite
- diabase dyke association of southeastern Finland. In: Haapala, I. \& Condie, K.C. (eds.) Precambrian Granitoids - Petrogenesis, Geochemistry and Metallogeny. Precambrian Research 51, 227-243.

Welin, E., Vaasjoki, M. \& Suominen, V. 1983. Age differences between $\mathrm{Rb}-\mathrm{Sr}$ whole rock and $\mathrm{U}-\mathrm{Pb}$ zircon ages of syn- and postorogenic Svecokarelian granitoids in Sottunga, SW Finland. Lithos 16, 297-305. 